\title{
ANALISIS KEPUASAN KONSUMEN DENGAN MENGGUNAKAN METODE CUSTOMER SATISFACTION INDEX (Studi Kasus : C'Bezt Taman Griya)
}

\author{
Pinondang Simanjuntak, I Ketut Satriawan*, Sri Mulyani \\ PS Teknologi Industri Pertanian, Fakultas Teknologi Pertanian, Universitas Udayana, Kampus Bukit \\ Jimbaran, Badung, Kode pos : 80361; Telp/Fax : (0361) 701801.
}

Diterima 28 Nopember 2018 / Disetujui 21 Maret 2019

\begin{abstract}
The purpose of this study was to know the attributes that are considered important by consumers and to know the level of customer satisfaction at C'Bezt Taman Griya. The method used is Slovin Method for determining samples and customer satisfaction index (CSI) method for data processing. Tests for reliability and validity were carried out at Jaya Fried Chicken Siligita and research site in C'Bezt Taman Griya. The number of samples used was 97 respondents. The attributes that are considered important by consumers based on the level of importance are the taste of food, the behavior of employees in serving consumers, and cleanliness of the location. Based on the level of satisfaction is the speed in serving consumers, taste of food, seriousness in serving consumers. The level of customer satisfaction C'Bezt Taman Griya is $74.63 \%$ with the level of Customer Satisfaction criteria that is satisfied. Keywords: Consumer Satisfaction, Consumen Satisfaction Index, C'Bezt.
\end{abstract}

*Korespondensi Penulis:

Email : satriawan@unud.ac.id 


\section{PENDAHULUAN}

Pertumbuhan penduduk Indonesia mengalami peningkatan jumlah setiap tahunnya. Berdasarkan data Badan Pusat Statistika tahun 2016, jumlah penduduk Indonesia sebanyak 261.1 juta jiwa. Peningkatan jumlah penduduk berdampak terhadap kebutuhan pangan yang semakin meningkat. Peningkatan kebutuhan pangan membuka lebar bisnis restoran terutama restoran cepat saji. Perkembangan restoran cepat saji di Indonesia sangat pesat terutama restoran cepat saji dibidang fried chicken, salah satunya adalah C'Bezt Fried Chicken. $C$ 'Bezt Fried Chicken merupakan salah satu restoran cepat saji yang menjual berbagai makanan dan minuman. C'Bezt Fried Chicken tersebar dibeberapa pulau di Indonesia yaitu: Sumatera, Jawa, Lombok dan Bali. Salah satu cabang C'Bezt Fried Chicken di Bali berlokasi di Jalan Danau Batur Raya, Taman Griya.

Kepuasan merupakan rasa senang konsumen setelah membandingkan antara persepsi atau kesannya terhadap kinerja atau hasil dari suatu produk (Kotler, 2002). Kepuasan konsumen merupakan respon konsumen terhadap suatu produk atau jasa yang muncul atas perbandingan antara ekspektasi dan persepsi yang diterimanya (Ambarini et al., 2014). Dari kedua defenisi tersebut dapat disimpulkan bahwa kepuasan konsumen merupakan hasil dari perbandingan respon antara persepsi dan ekspektasi yang diterima konsumen baik atau buruk. Terdapat sejumlah penelitian yang membahas tentang kepuasan konsumen. Pada penelitian Burger King yang berada di Bali menunjukkan bahwa kualitas layanan berpengaruh signifikan terhadap kepuasan konsumen (Sanjiwara et al., 2015).

C'Bezt Fried Chicken Taman Griya waktu pertama kali buka sangat ramai diminati konsumen. Setiap bulannya konsumen C'Bezt bisa mencapai 4.000 konsumen. Tahun 2018, konsumen C'Bezt mengalami penurunan dari 4.000 konsumen menjadi 3.000 konsumen setiap bulannya. Berdasarkan hal tersebut maka perlu dilakukan penelitian mengenai kepuasan konsumen di C'Bezt Fried Chicken Taman Griya.

Beberapa metode yang bisa digunakan untuk mengukur dan mengevaluasi atributatribut yang dimiliki oleh perusahaan berdasarkan tingkat kepentingannya seperti metode Customer Satisfaction Index (CSI), Importance Performance Analysis (IPA), Fuzzy-Servqual serta model Kano. Metode yang digunakan dalam penelitian ini adalah Customer Satisfaction Index. Customer Satisfaction Index digunakan untuk mengetahui tingkat kepuasan pengunjung secara menyeluruh dengan melihat tingkat kepentingan dari atribut-atribut produk/jasa. Customer Satisfaction Index merupakan indeks untuk menentukan tingkat kepuasan konsumen secara menyeluruh dengan pendekatan yang mempertimbangkan tingkat kepentingan dari atribut-atribut yang diukur (Syukri, 2014).

\section{METODE PENELITIAN}

Penelitian ini dilaksanakan di $C^{\prime} B e z t$ Taman Griya yang berlokasi di Jalan Danau Batur Raya, Taman Griya dan Laboratorium Sistem Manajemen Industri, Fakultas Teknologi Pertanian, Universitas Udayana. Penelitian dilaksanakan dari Juli hingga September 2018. Metode yang digunakan untuk analisis data adalah metode Customer Satisfaction Index (CSI) dan metode Slovin digunakan untuk menentukan jumlah sampel. Penelitian ini menggunakan kuisioner, kuisioner ditujukan terhadap konsumen C'Bezt Taman Griya di Jalan Danau Batur Raya, Taman Griya.

Tahapan penelitian dimulai dengan survei pendahuluan, dilakukan dengan cara observasi secara langsung ke lokasi 
penelitian untuk dapat mengetahui gambaran umum tentang Perusahan C'Bezt Taman Griya. Tahapan selanjutnya membuat rumusan masalah penelitian dan tujuan penelitian kemudian mengidentifikasi atribut penelitian untuk mendapatkan atribut-atribut kualitas produk dan pelayanan di C'Bezt Taman Griya, yang menjadi faktor pengaruh kepuasan konsumen. Atribut penelitian dapat dilihat pada Tabel 1.

Penentuan sampel dilakukan dengan menggunakan metode Slovin. Jumlah sampel yang digunakan adalah 97 responden dari
3.000 konsumen, kemudian dilakukan penyusunan kuisioner penelitian. Kuisioner penelitian diuji tingkat validitas dan reliabilitasnya, apabila sudah valid dan reliabel dilanjutkan ke tahap pengumpulan data. Tahap selanjutnya adalah analisis data dengan metode Customer Satisfaction Index menggunakan aplikasi Microsoft exel. Faktor-faktor yang diamati dalam penelitian ini adalah atribut-atribut yang dianggap penting oleh konsumen dan tingkat kepuasan konsumen di C'Bezt Taman Griya.

Tabel 1. Atribut penelitian

\begin{tabular}{|c|c|c|}
\hline No. & Kualitas Produk & Variabel \\
\hline \multirow[t]{3}{*}{1} & Makanan & Variasi menu makanan \\
\hline & & Penyajian/plating makanan \\
\hline & & Rasa makanan \\
\hline \multirow[t]{3}{*}{2} & Minuman & Variasi menu minuman \\
\hline & & Penyajian/plating minuman \\
\hline & & Rasa minuman \\
\hline \multirow[t]{4}{*}{3} & Harga & Kesesuaian harga makanan dengan porsi \\
\hline & & Kesesuaian harga minuman dengan porsi \\
\hline & & Kesesuaian harga makanan dengan kualitas \\
\hline & & Kesesuaian harga minuman dengan kualitas \\
\hline \multirow[t]{4}{*}{4} & Promosi & Penggunaan social media \\
\hline & & Potongan harga \\
\hline & & Member card \\
\hline & & Membuka booth dalam event \\
\hline \multirow[t]{7}{*}{5} & Tangible & Parkir \\
\hline & & Toilet \\
\hline & & Kebersihan lokasi \\
\hline & & Desain interior \\
\hline & & Peralatan yang digunakan \\
\hline & & Penampilan karyawan \\
\hline & & Fasilitas wifi \\
\hline \multirow[t]{2}{*}{6} & Reliability & Ketepatan penyajian pesanan \\
\hline & & Kecepatan waktu penyajian \\
\hline 7 & Responsiveness & Kecepatan dalam melayani konsumen \\
\hline \multirow[t]{3}{*}{8} & Assurance & $\begin{array}{l}\text { Pengetahuan karyawan terhadap menu ataupun produk } \\
\text { yang ditawarkan }\end{array}$ \\
\hline & & Kenyamanan konsumen pada saat berada di $C^{\prime} B e z t$ \\
\hline & & Perilaku karyawan dalam melayani konsumen \\
\hline 9 & Emphaty & $\begin{array}{l}\text { Pelayanan yang sama tanpa memandang status sosial } \\
\text { Kesungguhan dalam melavani konsumen }\end{array}$ \\
\hline
\end{tabular}




\section{HASIL DAN PEMBAHASAN}

\section{Analisis Reliabilitas dan Validitas}

Uji reliabilitas dan validitas dilakukan di Jaya Fried Chicken (JFC) Siligita. Berdasarkan uji reliabilitas kuisioner tingkat kepentingan dan tingkat kepuasan dengan menggunakan metode alpha Cronbach dan product moment didapat hasil koefisien alpha $(\alpha)$ sebesar 0.89 dan 0.93 , sedangkan $r$ tabel $(\alpha=0.1)$ sebesar 0.29. Dapat disimpulkan bawah setiap atribut tingkat kepentingan dan tingkat kepuasan kuisioner valid dan reliabel karena nilai alpha Cronbach dan product Moment yang didapat lebih besar dari nilai $r$ table.

\section{Karakteristik Responden}

Data profil responden di C'Bezt Taman Griya diperoleh dari kuisioner yang telah disebarkan sebelumnya. Dari 97 kuisioner yang telah disebarkan diperoleh data responden berjenis kelamin laki-laki sebanyak 40 orang $(41 \%)$ dan jenis kelamin perempuan sebanyak 57 orang (59\%). Dari 97 responden yang telah disebarkan, jumlah responden yang berumur 17 sampai 25 tahun sebanyak 69 orang $(71 \%)$, responden yang berumur 26 sampai 35 tahun sebanyak 16 orang (17\%) dan responden yang berumur 36 sampai 50 tahun sebanyak 12 orang (12\%). Berdasarkan jenis pekerjaan responden, dari 97 responden terdapat 47 orang (49\%) yang berstatus mahasiswa/pelajar, 12 orang (12\%) merupakan wiraswasta, 31 orang $(32 \%)$ merupakan pegawai swasta, dan 7 orang $(7 \%)$ merupakan ibu rumah tangga.

$\begin{array}{ccc}\text { Jenis } & \text { pekerjaan dengan tingkat } \\ \text { pengunjung } & \text { tertinggi } & \text { adalah }\end{array}$ mahasiswa/pelajar dan berdasarkan umur, tingkat pengunjung tertinggi adalah 17 sampai 25 tahun. Mahasiswa/pelajar menjadi pengunjung yang tertinggi dikarenakan C'Bezt Taman Griya dekat dengan lokasi kampus sehingga konsumen C'bezt Taman
Griya lebih banyak mahasiswa/pelajar. Hal ini didukung dengat tingat umur pengunjung yang tertinggi adalah 17 sampai 25 tahun. Dimana rata rata umur mahasiswa/ pelajar 17 sampi 25 tahun. Berdasarkan jenis kelamin, tingkat pengunjung tertinggi adalah wanita.

\section{Analisis Atribut yang Dianggap Penting oleh Konsumen}

Atribut dalam kuisioner yang dianggap penting oleh konsumen diperoleh dengan cara menghitung jumlah skor setiap atribut sehingga didapat atribut berdasarkan tingat kepentingannya. Semakin besar nilai skor yang didapat dalam setiap atribut maka semakin besar tingkat kepentingan atribut berdasarkan penilaian konsumen. Hasil perhitungan nilai atribut yang dianggap penting dapat dilihat pada Tabel 2 dan 3.

Atribut tingkat kepentingan yang mendapat skor rata-rata terbesar adalah atribut rasa makanan dengan skor rata-rata (4.76), perilaku karyawan dalam melayani konsumen (4.66), kebersihan lokasi (4.63), kenyamanan konsumen pada saat berada di C'Bezt (4.63), kebersihan toilet (4.6), dan rasa minuman (4.6). Atribut yang mendapat skor rata-rata terkecil adalah atribut membuat member card dengan skor rata-rata (3.22). Rasa makanan dan minuman merupakan faktor yang dianggap penting oleh konsumen. Rasa makanan dan minuman yang enak membuat konsumen merasa puas, jika konsumen puas terhadap rasa makanan maka konsumen akan kembali membeli makanan dan merekomendasikan makanan tersebut pada teman dan keluarga. Salah satu cara supaya konsumen nyaman di C'Bezt dengan menjaga kebersihan lokasi dan toilet supaya konsumen betah berada di C'bezt Taman Griya. Perilaku karyawan yang baik dapat meningkatkan rasa senang konsumen, salah satu cara meningkatkan perilaku karyawan kepada konsumen dengan mengucapkan salam dan senyum kepada konsumen. 
Tabel 2. Penilaian atribut oleh konsumen pada tingkat kepentingan

\begin{tabular}{|c|c|c|c|c|c|}
\hline No & Atribut & $\begin{array}{l}\text { Rata-Rata Tingkat } \\
\text { Kepentingan }\end{array}$ & No & Atribut & $\begin{array}{l}\text { Rata-Rata Tingkat } \\
\text { Kepentingan }\end{array}$ \\
\hline 1 & Rasa makanan & 4.76 & 16 & $\begin{array}{l}\text { Kesesuaian harga } \\
\text { makanan dengan } \\
\text { porsi }\end{array}$ & 4.44 \\
\hline 2 & $\begin{array}{l}\text { Perilaku karyawan } \\
\text { dalam melayani } \\
\text { konsumen }\end{array}$ & 4.66 & 17 & $\begin{array}{l}\text { Ketersediaan lahan } \\
\text { parkir }\end{array}$ & 4.35 \\
\hline 3 & Kebersihan lokasi & 4.63 & 18 & $\begin{array}{l}\text { Peralatan yang } \\
\text { digunakan }\end{array}$ & 4.21 \\
\hline 4 & $\begin{array}{l}\text { Kenyamanan } \\
\text { konsumen pada saat } \\
\text { berada di } C^{\prime} B e z t\end{array}$ & 4.63 & 19 & $\begin{array}{l}\text { Variasi menu } \\
\text { makanan }\end{array}$ & 4.18 \\
\hline 5 & Kebersihan toilet & 4.60 & 20 & Potongan harga & 4.18 \\
\hline 6 & Rasa Minuman & 4.60 & 21 & $\begin{array}{l}\text { Penampilan } \\
\text { karyawan }\end{array}$ & 4.15 \\
\hline 7 & $\begin{array}{l}\text { Kesesuian harga } \\
\text { makanan dengan } \\
\text { kualitas }\end{array}$ & 4.59 & 22 & $\begin{array}{l}\text { Variasi menu } \\
\text { minuman }\end{array}$ & 4.01 \\
\hline 8 & $\begin{array}{l}\text { Kesungguhan dalam } \\
\text { melayani konsumen }\end{array}$ & 4.58 & 23 & $\begin{array}{l}\text { Penyajian/Platting } \\
\text { makanan }\end{array}$ & 3.99 \\
\hline 9 & $\begin{array}{l}\text { Pengetahuan } \\
\text { karyawan terhadap } \\
\text { menu ataupun produk } \\
\text { yang ditawarkan }\end{array}$ & 4.56 & 24 & $\begin{array}{l}\text { Penyajian/Platting } \\
\text { minuman }\end{array}$ & 3.94 \\
\hline 10 & $\begin{array}{l}\text { Kesesuian harga } \\
\text { minuman dengan } \\
\text { kualitas }\end{array}$ & 4.56 & 25 & $\begin{array}{l}\text { Penggunaan social } \\
\text { media }\end{array}$ & 3.94 \\
\hline 11 & $\begin{array}{l}\text { Kecepatan dalam } \\
\text { melayani konsumen }\end{array}$ & 4.54 & 26 & $\begin{array}{l}\text { Ketersediaan } \\
\text { internet (wifi) }\end{array}$ & 3.76 \\
\hline 12 & $\begin{array}{l}\text { Pelayanan yang sama } \\
\text { tanpa memandang } \\
\text { status sosial }\end{array}$ & 4.54 & 27 & Desain interior & 3.69 \\
\hline 13 & $\begin{array}{l}\text { Kecepatan penyajian } \\
\text { pesanan }\end{array}$ & 4.52 & 28 & $\begin{array}{l}\text { Membuka booth } \\
\text { pada event-event }\end{array}$ & 3.42 \\
\hline 14 & $\begin{array}{l}\text { Kesesuaian harga } \\
\text { minuman dengan } \\
\text { porsi }\end{array}$ & 4.46 & 29 & $\begin{array}{l}\text { Membuat member } \\
\text { card }\end{array}$ & 3.22 \\
\hline 15 & $\begin{array}{l}\text { Ketepatan penyajian } \\
\text { pesanan }\end{array}$ & 4.45 & & & \\
\hline
\end{tabular}

Atribut tingkat kepuasan yang dianggap penting oleh konsumen yang mendapat skor rata-rata terbesar adalah atribut kecepatan dalam melayani konsumen (3.98), kesungguhan dalam melayani konsumen dan rasa makanan (3.97), ketepatan penyajian pesanan (3.95), kecepatan penyajian pesanan
(3.95), kesesuaian harga makanan dengan porsi (3.95), dan kesesuaian harga makanan dengan kualitas (3.95). Atribut yang mendapat skor rata-rata terkecil adalah ketersediaan internet/wifi (2.91). Kecepatan dalam melayani konsumen dianggap, konsumen menginginkan suatu palayanan 
yang cepat dan tidak menunggu lama dengan cara meningkatkan kecepatan dan ketepatan penyajian pesanan. Konsumen menginginkan kualitas produk yang bagus dan porsi makanan sesuai dengan harga yang dibayarkan karena konsumen tidak mau rugi. Harga yang dibayar harus sesuai dengan produk yang deterima. Pelayanan yang diberikan terhadap konsumen harus totalitas dan tidak memandang status sosial konsumen. Setiap kosumen memiliki hak dan kewajiban yang sama. Perbedaan palayanan terhadap konsumen membuat kesenjangan sosial dan rasa cemburu antar konsumen.

Tabel 3. Penilaian atribut oleh konsumen pada tingkat kepuasan

\begin{tabular}{|c|c|c|c|c|c|}
\hline No & Atribut & $\begin{array}{c}\text { Rata-Rata Tingkat } \\
\text { Kepentingan }\end{array}$ & No & Atribut & $\begin{array}{c}\text { Rata-Rata Tingkat } \\
\text { Kepentingan }\end{array}$ \\
\hline 1 & $\begin{array}{l}\text { Kecepatan dalam } \\
\text { melayani konsumen }\end{array}$ & 3.98 & 16 & $\begin{array}{l}\text { Penampilan } \\
\text { karyawan }\end{array}$ & 3.84 \\
\hline 2 & $\begin{array}{l}\text { Kesungguhan dalam } \\
\text { melayani konsumen }\end{array}$ & 3.97 & 17 & Rasa Minuman & 3.81 \\
\hline 3 & Rasa makanan & 3.97 & 18 & $\begin{array}{l}\text { Peralatan yang } \\
\text { digunakan }\end{array}$ & 3.80 \\
\hline 4 & $\begin{array}{l}\text { Ketepatan penyajian } \\
\text { pesanan }\end{array}$ & 3.95 & 19 & $\begin{array}{l}\text { Penyajian/Platting } \\
\text { yang menarik }\end{array}$ & 3.69 \\
\hline 5 & $\begin{array}{l}\text { Kecepatan penyajian } \\
\text { pesanan }\end{array}$ & 3.95 & 20 & $\begin{array}{l}\text { Variasi menu } \\
\text { minuman }\end{array}$ & 3.61 \\
\hline 6 & $\begin{array}{l}\text { Kesesuaian harga } \\
\text { makanan dengan porsi }\end{array}$ & 3.95 & 21 & Desain interior & 3.60 \\
\hline 7 & $\begin{array}{l}\text { Kesesuian harga } \\
\text { makanan dengan } \\
\text { kualitas }\end{array}$ & 3.95 & 22 & $\begin{array}{l}\text { Ketersediaan lahan } \\
\text { parkir }\end{array}$ & 3.58 \\
\hline 8 & $\begin{array}{l}\text { Pelayanan yang sama } \\
\text { tanpa memandang } \\
\text { status sosial }\end{array}$ & 3.93 & 23 & $\begin{array}{l}\text { Penyajian/Platting } \\
\text { yang menarik }\end{array}$ & 3.53 \\
\hline 9 & $\begin{array}{l}\text { Pengetahuan } \\
\text { karyawan terhadap } \\
\text { menu ataupun produk } \\
\text { yang ditawarkan }\end{array}$ & 3.92 & 24 & Kebersihan toilet & 3.44 \\
\hline 10 & Variasi menu makanan & 3.91 & 25 & Potongan harga & 3.40 \\
\hline 11 & $\begin{array}{l}\text { Kenyamanan } \\
\text { konsumen pada saat } \\
\text { berada di } C^{\prime} B e z t\end{array}$ & 3.90 & 26 & $\begin{array}{l}\text { Penggunaan social } \\
\text { media }\end{array}$ & 3.31 \\
\hline 12 & $\begin{array}{l}\text { Perilaku karyawan } \\
\text { dalam melayani } \\
\text { konsumen }\end{array}$ & 3.90 & 27 & $\begin{array}{l}\text { Membuka booth } \\
\text { pada event-event }\end{array}$ & 3.20 \\
\hline 13 & $\begin{array}{l}\text { Kesesuaian harga } \\
\text { minuman dengan porsi }\end{array}$ & 3.89 & 28 & $\begin{array}{l}\text { Membuat member } \\
\text { card }\end{array}$ & 3.03 \\
\hline 14 & $\begin{array}{l}\text { Kesesuian harga } \\
\text { minuman dengan } \\
\text { kualitas }\end{array}$ & 3.88 & 29 & $\begin{array}{l}\text { Ketersediaan } \\
\text { internet (wifi) }\end{array}$ & 2.91 \\
\hline 15 & Kebersihan lokasi & 3.84 & & $\begin{array}{l}\text { Penampilan } \\
\text { karyawan }\end{array}$ & \\
\hline
\end{tabular}

Nilai rata-rata setiap atribut kuisioner

pada tingkat kepuasan lebih besar dari pada 
nilai rata rata setiap atribut tingkat kepentingan. Hal ini berarti, pelayanan yang diberikan C'Bezt Taman Griya belum sesuasi dengan yang diinginkan konsumen, sehingga konsumen C'Bezt Taman Griya mengalami penurunan jumlah dari 4.000 menjadi 3.000 konsumen.

\section{Analisis Tingkat Kepuasan Konsumen}

Setelah dilakukan penelitian dan perhitungan CSI, didapat score tingkat kepuasan konsumen C'Bezt Taman Griya sebesar $74.63 \%$. Hasil perhitungan tingkat Kepuasan Konsumen didapat dengan cara: jumlah total Weight Score yang didapat (3.73) dibagi dengan nilai skala likert terbesar (5) kemudian dikali dengan $100 \%$. Hasil ini sesuai dengan pendapat Sunaryo et al., (2015) yang menyatakan bahwa nilai berada pada kriteris nilai CSI puas. Score kriteria puas memiliki kisaran 61\%-80\%. Hasil perhitungan Nilai CSI dapat dilihat pada Tabel 4.

Tabel 4. Analisis CSI di C'Bezt Taman Griya

\begin{tabular}{|c|c|c|c|c|c|}
\hline No & Atribut & $\begin{array}{c}\text { Rata-rata } \\
\text { Tingkat } \\
\text { Kepentingan (Y) }\end{array}$ & $\begin{array}{c}\text { Rata-rata } \\
\text { Tingkat } \\
\text { Kepuasan }(X)\end{array}$ & $\begin{array}{l}\text { Weight } \\
\text { Factor } \\
(\%)\end{array}$ & $\begin{array}{c}\text { Weight } \\
\text { Score }\end{array}$ \\
\hline 1 & Ketersediaan lahan parkir & 4.35 & 3.58 & 3.50 & 0.13 \\
\hline 2 & Kebersihan toilet & 4.60 & 3.44 & 3.70 & 0.13 \\
\hline 3 & Kebersihan lokasi & 4.63 & 3.84 & 3.73 & 0.14 \\
\hline 4 & Desain interior & 3.69 & 3.60 & 2.97 & 0.11 \\
\hline 5 & Peralatan yang digunakan & 4.21 & 3.80 & 3.39 & 0.13 \\
\hline 6 & Penampilan karyawan & 4.15 & 3.84 & 3.35 & 0.13 \\
\hline 7 & Ketersediaan internet (wifi) & 3.76 & 2.91 & 3.03 & 0.09 \\
\hline 8 & Ketepatan penyajian pesanan & 4.45 & 3.95 & 3.59 & 0.14 \\
\hline 9 & Kecepatan penyajian pesanan & 4.52 & 3.95 & 3.64 & 0.14 \\
\hline 10 & $\begin{array}{l}\text { Kecepatan dalam melayani } \\
\text { konsumen }\end{array}$ & 4.54 & 3.98 & 3.65 & 0.15 \\
\hline 11 & $\begin{array}{l}\text { Pengetahuan karyawan } \\
\text { terhadap menu ataupun } \\
\text { produk yang ditawarkan }\end{array}$ & 4.56 & 3.92 & 3.67 & 0.14 \\
\hline 12 & $\begin{array}{l}\text { Kenyamanan konsumen pada } \\
\text { saat berada di } C^{\prime} B e z t\end{array}$ & 4.63 & 3.90 & 3.73 & 0.15 \\
\hline 13 & $\begin{array}{l}\text { Perilaku karyawan dalam } \\
\text { melayani konsumen }\end{array}$ & 4.66 & 3.90 & 3.75 & 0.15 \\
\hline 14 & $\begin{array}{l}\text { Pelayanan yang sama tanpa } \\
\text { memandang status sosial }\end{array}$ & 4.54 & 3.93 & 3.65 & 0.14 \\
\hline 15 & $\begin{array}{l}\text { Kesungguhan dalam } \\
\text { melayani konsumen }\end{array}$ & 4.58 & 3.97 & 3.69 & 0.15 \\
\hline 16 & Variasi menu makanan & 4.18 & 3.91 & 3.36 & 0.13 \\
\hline 17 & Penyajian/Platting makanan & 3.99 & 3.69 & 3.21 & 0.12 \\
\hline 18 & Rasa makanan & 4.76 & 3.97 & 3.84 & 0.15 \\
\hline 19 & Variasi menu minuman & 4.01 & 3.61 & 3.23 & 0.12 \\
\hline 20 & Penyajian/Platting minuman & 3.94 & 3.53 & 3.17 & 0.11 \\
\hline 21 & Rasa Minuman & 4.60 & 3.81 & 3.70 & 0.14 \\
\hline 22 & $\begin{array}{l}\text { Kesesuaian harga makanan } \\
\text { dengan porsi }\end{array}$ & 4.44 & 3.95 & 3.58 & 0.14 \\
\hline
\end{tabular}




\begin{tabular}{rlcccc}
\hline 23 & $\begin{array}{l}\text { Kesesuaian harga minuman } \\
\text { dengan porsi }\end{array}$ & 4.46 & 3.89 & 3.60 & 0.14 \\
24 & $\begin{array}{l}\text { Kesesuian harga makanan } \\
\text { dengan kualitas }\end{array}$ & 4.59 & 3.95 & 3.70 & 0.15 \\
25 & $\begin{array}{l}\text { Kesesuian harga minuman } \\
\text { dengan kualitas }\end{array}$ & 4.56 & 3.88 & 3.67 & 0.14 \\
26 & Penggunaan Social Media & 3.94 & 3.31 & 3.17 & 0.10 \\
27 & Potongan harga & 4.18 & 3.40 & 3.36 & 0.11 \\
28 & Membuat member card & 3.22 & 3.03 & 2.59 & 0.08 \\
29 & $\begin{array}{l}\text { Membuka Booth pada } \text { event- } \\
\text { event }\end{array}$ & 3.42 & 3.20 & 2.76 & 0.09 \\
\hline Total & & & & 100.00 & 3.73 \\
\hline
\end{tabular}

\section{KESIMPULAN}

\section{Kesimpulan}

Berdasarkan penelitian yang telah dilakukan maka dapat disimpulkan beberapa hal sebagai berikut :

1. Atribut-atribut yang dianggap penting oleh konsumen untuk tingkat kepentingan adalah rasa makanan (4.76), sedangkan atribut tingkat kepuasan yang dianggap penting oleh konsumen adalah kecepatan dalam melayani konsumen (3.98).

2. Tingkat kepuasan konsumen C'Bezt Taman Griya sebesar $74.63 \%$ dengan tingkat kriteria Customer Satisfaction yaitu puas.

\section{Saran}

Berdasarkan hasil penelitian ini dapat disarankan beberapa hal sebagai berikut :

1. C'Bezt Taman Griya sebaiknya meningkatkan semua pelayanan karena semua pelayanan di C'Bezt Taman Griya belum sesuai dengan harapan konsumen.

2. C'Bezt Taman Griya sebaiknya lebih meningkatkan kebersihat toilet agar konsumen lebih nyaman.

\section{DAFTAR PUSTAKA}

Ambarini, A., D. Novirani dan A. Bakar. 2014. Upaya Peninngkatan Kepuasan Konsumen Indosat Berdasarkan
TelecommunicationService Quality dengan Menggunakan Structural Equation Modeling (SEM). Reka Integra. 02(01): 204-2016.

Anggraini, L. D., Deoranto, P., \& Ikasari, D. M. 2015. Analisis Persepsi Konsumen Menggunakan Metode Importance Performance Analysis dan Customer Satisfaction Index. Industri. 04(02): 74-81.

Kotler, P. 2002. Manajemen Pemasaran. PT. Prehallindo, Jakarta.

Lodhita, H. E., I. Santoso dan S. Anggraini. 2013. Pengaruh Kualitas Pelayanan Terhadap Kepuasan Konsumen Menggunakan Metode IPA (Importance Performance Analysis) dan CSI (Customer Satisfaction Index). Teknologi Industri dan Pertanian - (1): 1-10

Sanjiwara, M., K. Jayanegara dan I.E. Kencana. 2015. Analisis Kepuasan Konsumen Restoran Cepat Saji Menggunakan Metode Partial Least Square (Studi kasus Burger King Bali). E-Jurnal Matematika. 4(3): 98103.

Sugiyono. 2013. Statistika Untuk Penilitian. CV. Alfabeta, Bandung.

Sunaryo., V.N. Helia dan A.A. Handriati. 
2015. Analisis Kualitas Pelayanan

Publik Terhadap Kepuasan

Konsumen dengan Menggunakan Metode Servperf-IPA-CSI. Teknoin.21(4): $\quad$ 178-190.

Syukri, S. H. 2014. Penerapan Customer Satisfaction Index (CSI) dan Analisis GAB Kualitas Pelayanan Trans Jogja. Ilmiah Teknik Industri.13(2): 103111. 